\title{
KOMUNIKASI LINTAS BUDAYA DI INSTITUSI PENDIDIKAN Studi Kasus: Perguruan Tinggi Mayoritas Mahasiswa Tionghoa dengan Pengajar Pribumi
}

\author{
Meilani Dhamayanti \\ meilanidhamayanti@gmail.com \\ Dosen Ilmu Komunikasi YAI
}

\begin{abstract}
Communication and culture have a reciprocal relationship of mutual influence. In the daily life, communication and culture have a very important role. In the educational institutions communication and culture are often touch to each other therefore study on communication and culture in the educational institution is very needed since the diversity of life itself. This research is using cross cultural communication theory and qualitative method to describe the research process. The research conclusion is that it needs an active role of the lecturer so that barriers within the cross cultural communication can be solved. In other side it is also important to have collaboration between students and lecturers to achieve the learning outcome.

Key Words: Cross Cultural Communication, Educational Institution
\end{abstract}

Keywords: Cross Cultural Communication, Educational Institution

\section{Pendahuluan}

Pendidikan

dan

kebudayaan memiliki keterkaitan yang sangat erat. Bahkan keduanya memiliki peran penting dalam kehidupan suatu bangsa. Pendidikan tidak bisa dilepaskan dari nilai-nilai budaya. Keberadaan pendidikan dan budaya saling mendukung dan melengkapi. Melalui pendidikan, transfer nilai-nilai

\begin{abstract}
Abstrak
Komunikasi dan budaya memiliki hubungan timbal balik yang saling mempengaruhi. Dalam kehidupan sehari-hari komunikasi dan budaya memiliki peranan yang sangat penting. Melalui institusi pendidikan, komunikasi dan budaya kerap bersinggungan. Karenanya kajian komunikasi dan budaya di institusi pendidikan sangat diperlukan mengingat kehidupan semakin beragam. Penelitian ini menggunakan teori komunikasi lintas budaya dan metodologi kualitatif yang bertujuan untuk menggambarkan hasil penelitian. Adapun kesimpulan dari penelitian ini adalah diperlukan peran aktif dosen agar hambatan komunikasi lintas budaya dalam institusi pendidikan bisa dihadapi. Di sisi lain penting pula adanya kerjasama antara dosen dan mahasiswa agar tujuan pembelajaran dapat tercapai.
\end{abstract}

Kata Kunci: Komunikasi Lintas Budaya, Intitusi Pendidikan

budaya dari generasi ke generasi bisa dilakukan. Proses pelestarian kebudayaan pun dilakukan melalui pendidikan.

Pendidikan sangat berperan dalam mengembangkan karakter suatu bangsa. Di satu sisi karakter suatu bangsa sangat dipengaruhi kebudayaan. Sebagai bangsa yang memiliki keberagaman budaya, bangsa Indonesia 
sangat berharap agar pendidikan dapat menjadikan karakter bangsa semakin kuat.

Kemajemukan bangsa Indonesia bukan tidak mungkin menjadikan persoalan dalam proses pendidikan. Hal ini dikarenakan dapat saja keberagaman yang ada memiliki perbedaan komunikasi. Tidak hanya itu, perbedaan seperti pengalaman, pendidikan, nilai, dan motivasi sangat mungkin menjadi hambatan dalam proses komunikasi.

Komunikasi pada sebuah institusi pendidikan dapat saja memiliki hambatan. Dalam konteks Institusi Perguruan Tinggi, keberhasilan komunikasi sangat tergantung pada kesamaan persepsi antara dosen dengan mahasiswa. Dosen sebagai sosok yang melakukan transfer informasi kepada mahasiswanya sering menemukan hambatan. Terlebih mahasiswa sebagai insan muda yang beranjak dewasa, memiliki konsepsi sendiri tentang nilai dan motivasinya dalam belajar.

Hambatan dalam komunikasi transbudaya, dapat terjadi bila ada perbedaan latar belakang budaya yang cukup menyolok, misalnya pada sekolah-sekolah internasional. Pada sekolah internasional, terlihat keberagaman siswa serta pengajar. Keberagaman ini tentunya akan membedakan cara berkomunikasi. Hal ini dapat dipahami mengingat masingmasing negara atau bangsa memiliki kebudayaan masing-masing. Di satu sisi, kebudayaan itu melahirkan kebiasaan, nilai, norma serta komunikasi verbal dan non verbal yang berbeda.

Hambatan juga dapat terjadi bila terdapat perbedaan latar belakang budaya mayoritas dengan minoritas dalam sebuah institusi pendidikan. Misalnya institusi yang mayoritas mahasiswanya adalah etnis China dan pribumi sebagai pengajarnya. Walau dalam hal ini sama-sama berkewarganegaraan Indonesia, namun latar belakang budaya secara histori berbeda sehingga otomatis kebiasaan, nilai dan norma pun berbeda.

Di Jakarta, ada beberapa institusi pendidikan yang mayoritas mahasiswanya adalah etnis China, seperti Universitas Pelita Harapan (UPH), Bina Nusantara (Binus) serta Universitas Bunda Mulia (UBM). Keberagaman budaya yang terlihat pada institusi pendidikan bisa menjadi sebuah harmoni kebersamaan. Namun, sangat mungkin juga terjadi akan tercipta hambatan komunikasi lintas budaya. Tujuan dari riset ini adalah untuk mengetahui hambatan yang biasa terjadi pada komunikasi lintas budaya di institusi pendidikan dan bagaimana praktisi pendidikan seperti dosen dalam menyikapi hambatan yang terjadi demi terselenggaranya komunikasi yang efektif.

\section{Komunikasi Lintas Budaya}

Komunikasi secara singkat dapat diartikan sebagai proses penyampaian pesan dari suatu pihak ke pihak lainnya. Proses pertukaran pesan tersebut bisa dikatakan adalah salah satu faktor penting dalam kehidupan manusia. Mungkin dulu, manusia hanya berkomunikasi dengan sekitarnya dan secara geografis berjarak dekat. Namun, seiring kemajuan jaman, berbagai macam teknologi bermunculan. Hal tersebut mengakibatkan manusia tidak lagi hanya berkomunikasi dengan 'tetangga-tetangganya', namun juga dapat berkomunikasi dengan manusia dari masyarakat lain di belahan dunia lain pula. Proses ini yang disebut komunikasi lintas budaya. Definisi komunikasi lintas budaya adalah suatu proses peralihan ide dari dua kebudayaan atau lebih, yang mengakibatkan berkembangnya suatu kebudayaan, hancurnya suatu 
kebudayaan atau pelahiran budaya baru (akulturasi).

$$
\text { Tentunya, }
$$

masyarakat berarti perbedaan kebudayaan, yang bila ditelaah lebih dalam berarti perbedaan cara bertingkah laku, perbedaan pandangan, perbedaan sistem kepercayaan, dan sebagainya. Hal inilah yang jadi inti kajian ilmu komunikasi lintas budaya. Singkatnya, alasan mengapa kita harus mempelajari ilmu komunikasi lintas budaya, agar tidak terjadi kesalahpahaman di suatu pihak yang akhirnya bisa mengakibatkan konflik.

Pada jaman sekarangi, kita sering menemui situasi dimana kita harus berhadapan dengan suatu pihak yang memiliki kebudayaan yang berbeda dengan kita. Begitu juga dengan orang lain yang bertemu orang lain lagi dengan kebudayaan yang tentunya berbeda pula. Menanggapi pernyataan-pernyataan di atas, bukan berarti kita harus memandang keragaman kebudayaan yang dimiliki manusia itu bersifat buruk atau negatif, sehingga kita harus meleburkan berbagai kebudayaan yang masingmasing memiliki kekayaannya tersendiri menjadi satu kebudayaan yang utama dan supreme. Kebudayaan sangatlah penting bagi masyarakatnya, sebagai 'pembatas' dalam kehidupan mereka serta sebagai harta warisan bagi keturunan-keturunan mereka.

\section{Kebudayaan}

Kebudayaan sangat erat hubungannya dengan masyarakat. Melville J. Herskovits dan Bronislaw Malinowski mengemukakan tentang Cultural-Determinism yang artinya bahwa segala sesuatu yang terdapat dalam masyarakat ditentukan oleh kebudayaan yang dimiliki oleh masyarakat itu sendiri. (Sulasman dan Setia Gumilar, 2013 : 18)
Sementara itu Herskovits memandang kebudayaan sebagai sesuatu yang turun temurun dari satu generasi ke generasi yang lain, yang kemudian disebut sebagai superorganic. (Sulasman dan Setia Gumilar, 2013 : 18)

Menurut Andreas Eppink, kebudayaan mengandung keseluruhan pengertian nilai sosial, norma sosial, ilmu pengetahuan serta keseluruhan struktur-struktur sosial, religius, dan lain-lain, tambahan lagi segala pernyataan intelektual dan artistik yang menjadi ciri khas suatu masyarakat.

Menurut Edward Burnett Tylor, kebudayaan merupakan keseluruhan yang kompleks, yang di dalamnya terkandung pengetahuan, kepercayaan, kesenian, moral, hukum, adat istiadat, dan kemampuan-kemampuan lain yang didapat seseorang sebagai anggota masyarakat. Sementara itu menurut Selo Soemardjan dan Soelaiman Soemardi, kebudayaan adalah sarana hasil karya, rasa, dan cipta masyarakat. (Sulasman dan Setia Gumilar, 2013: 19)

Dari berbagai definisi tersebut, dapat diperoleh pengertian mengenai kebudayaan adalah sesuatu yang akan mempengaruhi tingkat pengetahuan dan meliputi sistem ide atau gagasan yang terdapat dalam pikiran manusia, sehingga dalam kehidupan sehari-hari, kebudayaan itu bersifat abstrak.

Sedangkan perwujudan kebudayaan adalah benda-benda yang diciptakan oleh manusia sebagai makhluk yang berbudaya, berupa perilaku dan benda-benda yang bersifat nyata, misalnya pola-pola perilaku, bahasa, peralatan hidup, organisasi sosial, religi, seni, dan lain-lain, yang kesemuanya ditujukan untuk membantu manusia dalam melangsungkan kehidupan bermasyarakat.

Kebudayaan sebagai hasil budi manusia, dalam hal berbagai bentuk dan menifestasinya, dikenal sepanjang 
sejarah sebagai milik manusia yang tidak kaku, melainkan selalu berkembang dan berubah dan menuntut manusia untuk menyesuaikan diri dengan perubahan-perubahan kultural dan tantangan zaman tradisional untuk memasuki zaman modern.

Manusia sebagai mahluk berakal dan berbudaya selalu berupaya untuk mengadakan perubahan-perubahan. Dengan sifatnya yang kreatif dan dinamis manusia terus berevolusi meningkatkan kualitas hidup yang semakin terus maju, ketika alamlah yang mengendalikan manusia dengan sifatnya yang tidak iddle curiousity (rasa keingintahuan yang terus berkembang) makin lama daya rasa, cipta dan karsanya telah dapat mengubah alam menjadi sesuatu yang berguna, maka alamlah yang dikendalikan oleh manusia.

Budaya diartikan sebagai keseluruhan sistem berpikir, nilai, moral, norma, dan keyakinan (belief) manusia yang dihasilkan masyarakat. Sistem berpikir, nilai, moral, norma, dan keyakinan itu adalah hasil dari interaksi manusia dengan sesamanya dan lingkungan alamnya. Sistem berpikir, nilai, moral, norma dan keyakinan itu digunakan dalam kehidupan manusia dan menghasilkan sistem sosial, sistem ekonomi, sistem kepercayaan, sistem pengetahuan, teknologi, seni, dan sebagainya. Manusia sebagai makhluk sosial menjadi penghasil sistem berpikir, nilai, moral, norma, dan keyakinan; akan tetapi juga dalam interaksi dengan sesama manusia dan alam kehidupan, manusia diatur oleh sistem berpikir, nilai, moral, norma, dan keyakinan yang telah dihasilkannya. Ketika kehidupan manusia terus berkembang, maka yang berkembang sesungguhnya adalah sistem sosial, sistem ekonomi, sistem kepercayaan, ilmu, teknologi, serta seni. Pendidikan merupakan upaya terencana dalam mengembangkan potensi peserta didik, sehingga mereka memiliki sistem berpikir, nilai, moral, dan keyakinan yang diwariskan masyarakatnya dan mengembangkan warisan tersebut ke arah yang sesuai untuk kehidupan masa kini dan masa mendatang.

\section{Kebudayaan material}

Kebudayaan material mengacu pada semua ciptaan masyarakat yang nyata dan konkret. Termasuk dalam kebudayaan material ini adalah temuantemuan yang dihasilkan dari suatu penggalian arkeologi: mangkuk tanah liat, perhiasan, senjata, dan seterusnya. Kebudayaan material juga mencakup barang-barang, seperti televisi, pesawat terbang, stadion olahraga, pakaian, gedung pencakar langit, dan mesin cuci.

\section{Kebudayaan nonmaterial}

Kebudayaan nonmaterial adalah ciptaan-ciptaan abstrak yang diwariskan dari generasi ke generasi, misalnya berupa dongeng, cerita rakyat, dan lagu atau tarian tradisional.

\section{Pendidikan}

Pendidikan adalah suatu usaha yang sadar dan sistematis dalam mengembangkan potensi peserta didik. Pendidikan adalah juga suatu usaha masyarakat dan bangsa dalam mempersiapkan generasi mudanya bagi keberlangsungan kehidupan masyarakat dan bangsa yang lebih baik di masa depan. Keberlangsungan itu ditandai oleh pewarisan budaya dan karakter yang telah dimiliki masyarakat dan bangsa. Oleh karena itu, pendidikan adalah proses pewarisan budaya dan karakter bangsa bagi generasi muda dan juga proses pengembangan budaya dan karakter bangsa untuk peningkatan kualitas kehidupan masyarakat dan bangsa di masa mendatang. Dalam proses pendidikan budaya dan karakter 
bangsa, secara aktif peserta didik mengembangkan potensi dirinya, melakukan proses internalisasi, dan penghayatan.

Adapun menurut Carter V. Good dalam Dictionary of Education (1959) bahwa pendidikan itu mengandung pengertian:

1. Proses perkembangan kecakapan seseorang dalam bentuk sikap dan prilaku yang berlaku dalam masyarakatnya;

2. Proses sosial dimana seseorang dipengaruhi oleh sesuatu lingkungan yang terpimpin (misalnya sekolah) sehingga ia dapat mencapai kecakapan sosial dan mengembangkan pribadinya.

Sedangkan menurut konsep yang disampaikan Samovar dikatakan bahwa budaya tidak dapat dipisahkan hubungannya dari pendidikan: orang yang dibesarkan dalam budaya akan belajar sesuai dengan apa yang dibutuhkan budaya mereka. Walaupun secara biologis manusia sama, tetapi karena pengalaman budaya, secara sosial akan tumbuh berbeda. Sekolah mewakili salah satu dari pengalaman penting tersebut. Sekolah juga menjadi sebuah konteks dimana baik proses sosialisasi maupun pembelajaran berlangsung. (Samovar, 2010: 382)

Menurut Hasan Langgulung
dalam "Asas- asas Pendidikan" bahasannya mengenai pendidikan adalah aktifitas yang dikerjakan oleh pendidikan dan filsafat untuk menjelaskan proses menyelaraskan, mengkritik dan merubahnya berdasar masalah-masalah kontradiksi budaya.

Pendidikan merupakan kegiatan yang dilakukan oleh pendidik dan filsuf untuk menerangkan, menyelaraskan, dan merubah proses pendidikan dengan persoalan-persoalan kebudayaan dan unsur-unsur yang bertentangan didalamnya. Dilihat dari sudut pandang individu, pendidikan merupakan usaha untuk menimbang dan menghubungkan potensi individu. Maka sudah jelas bahwa pendidikan dan kebudayaan sangat erat hubungan karena keduanya berkesinambungan, keduanya saling mendukung satu sama lainnya. Dalam konteks ini dapat dilihat hubungan antara pendidikan dengan tradisi budaya serta kepribadian suatu masyarakat betapapun sederhananya masyarakat tersebut. Hal ini dapat dilihat bahwa tradisi sebagai muatan budaya senantiasa terlestarikan dalam setiap masyarakat, dari generasi ke generasi. Hubungan ini tentunya hanya akan mungkin terjadi bila para pendukung nilai tersebut dapat menuliskannya kepada generasi mudanya sebagai generasi penerus.

Pendidikan selalu berubah sesuai perkembangan kebudayaan, karena pendidikan merupakan proses transfer kebudayaan dan sebagai cermin nilai-nilai kebudayaan (pendidikan bersifat reflektif). Pendidikan juga bersifat progresif, yaitu selalu mengalami perubahan perkembangan sesuai tuntutan perkembangan kebudayaan. Kedua sifat tersebut berkaitan erat dan terintegrasi. Untuk itu perlu pendidikan formal dan informal (sengaja diadakan atau tidak). Perbedaan kebudayaan menjadi cermin bagi bangsa lain, membuat perbedaan sistem, isi dan pendidikan pengajaran sekaligus menjadi cermin tingkat pendidikan dan kebudayaan.

\section{Hubungan Kebudayaan dengan Pendidikan}

Pendidikan secara praktis tak dapat dipisahkan dengan nilai-nilai budaya. Dalam menjaga dan melestarikan kebudayaan sendiri, secara proses transfer yang paling efektif adalah melalui pendidikan. Hubungan keduanya sangat erat karena saling melengkapi dan mendukung antara satu 
sama lain. Tujuan pendidikan pun adalah melestarikan dan selalu meningkatkan kebudayaan itu sendiri, dengan adanya pendidikanlah kita bisa mentransfer kebudayaan dari generasi ke generasi selanjutnya. Dan juga kita sebagai masyarakat mencita-citakan terwujudnya masyarakat dan kebudayaan yang lebih baik ke depannya, maka sudah dengan sendirinya pendidikan kitapun harus lebih baik lagi.

Kebudayaan sebagai hasil budi manusia, dalam hal berbagai bentuk dan menifestasinya, dikenal sepanjang sejarah sebagai milik manusia yang tidak kaku, melainkan selalu berkembang dan berubah dan membina manusia untuk menyesuaikan diri dengan perubahan-perubahan kultural dan tantangan jaman tradisional untuk memasuki jaman modern. Manusia sebagai mahluk berakal dan berbudaya selalu berupaya untuk mengadakan perubahan-perubahan. Dengan sifatnya yang kreatif dan dinamis manusia terus berevolusi meningkatkan kualitas hidup yang semakin maju, sementara alam dengan caranya turut mengendalikan sifat manusia.

Kebudayaan merupakan karya manusia yang mencakup diantaranya filsafat, kesenian, kesusasteraan, agama, penafsiran dan penilaian mengenai lingkungan. Dalam pengertian yang sederhana dan umum makna pendidikan adalah sebagai usaha manusia untuk menumbuhkan dan mengembangkan potensi-potensi pembawaan baik jasmani maupun rohani sesuai dengan nilai-nilai yang ada dalam masyarakat.

Transfer nilai-nilai budaya dimiliki paling efektif adalah melalui proses pendidikan. Dalam masyarakat modern proses pendidikan tersebut didasarkan pada program pendidikan secara formal. Oleh sebab itu dalam penyelenggarannya dibentuk kelembagaan pendidikan formal. Seperti dikemukakan Hasan Langulung dalam “Asas-asa Pendidikan" bahwa pendidikan mencakup dua kepentingan utama, yaitu pengembangan potensi individu dan pewarisan nilai-nilai budaya. Maka sudah jelas bahwa kedua hal tersebut yaitu pendidikan dan kebudayaan berkaitan erat dengan pandangan hidup suatu masyarakat atau bangsa, kedua hal tersebut tidak dapat dipisahkan karena saling membutuhkan antara satu sama lainnya. Dikatakan dalam pendapat tersebut bahwa pendidikan berhubungan dengan individu dan masyarakat, akan tetapi dapat dilihat bagaimana garis hubung antara pendidikan dan sumber daya manusia. Dari sudut pandangan individu pendidikan merupakan usaha untuk mengembangkan potensi individu, sebaliknya dari sudut pandang kemasyarakatan pendidikan adalah sebagai pewarisan nilai-nilai budaya. Dalam pandangan ini, pendidikan mengemban dua tugas utama, yaitu peningkatan potensi individu dan pelestarian nilai-nilai budaya. Manusia sebagai mahluk berbudaya, pada hakikatnya adalah pencipta budaya itu sendiri. Budaya itu kemudian meningkat sejalan dengan peningkatan potensi manusia pencipta budaya itu.

Dalam konteks ini dapat dilihat hubungan antara pendidikan dengan tradisi budaya serta kepribadian suatu masyarakat betapapun sederhananya masyarakat tersebut. Hal ini dapat dilihat bahwa tradisi sebagai muatan budaya senantiasa terlestarikan dalam setiap masyarakat, dari generasi ke generasi. Hubungan ini tentunya hanya akan mungkin terjadi bila para pendukung nilai tersebut dapat menuliskannya kepada generasi mudanya sebagai generasi penerus. Transfer nilai-nilai budaya dimiliki paling efektif adalah melalui proses 
pendidikan. Dalam masyarakat modern proses pendidikan tersebut didasarkan pada program pendidikan secara formal. Oleh sebab itu dalam penyelenggarannya dibentuk kelembagaan pendidikan formal.

Pembahasan budaya dan pendidikan juga disinggung oleh Samovar dalam bukunya "Komunikasi Lintas Budaya" . Menurut Samovar pendidikan dipengaruhi oleh budaya dan subkultur. Komunikasi yang baik penting dalam masyarakat. Dan secara ringkas menurut Samovar ini dapat terlihat dan tumbuh dalam institusi pendidikan yang berwawasan multikulural. Ada beberapa alasan mengapa kita perlu mempelajari pendidikan dan budaya, yaitu: pertama, kita dapat mempelajari persepsi dan pendekatan suatu budaya pada pendidikan. Pemahaman arti pendidikan bagi setiap bangsa berbeda beda. Kedua, tujuan umum pendidikan atau sekolah erat hubungannya dengan kemampuan intelektual atau fungsi sosial yang diasosiasikan pada masyarakat umumnya. Ketiga, pengaruh budaya pada pendidikan adalah menyadari pengetahuan informal suatu budaya. (Samovar: 2010 : 394)

\section{Pembahasan}

Antonius Philip, mahasiswa, menegaskan dari sisi bahasa tidak ada hambatan yang berarti dalam sebuah komunikasi lintas budaya di institusi pendidikan. Karena bahasa yang digunakan adalah bahasa Indonesia. Menurut Philip:

"Pernah juga mendapat dosen yang suka menyelipkan kata kata daerah. Saya gak ngerti. Mahasiswa lain juga gak ngerti. Jadi kami saling tanya. Tapi saya pribadi berusaha memahami mungkin dosen yang bersangkutan bukan asli Jakarta. Jadi bahasa daerahnya masih kental."

Hal senada disampaikan oleh Erna Mariana, dosen senior, mengajar di beberapa perguruan tinggi, menegaskan bahwa dalam aktifitas belajar mengajar di kelas, tidak ada hambatan dari segi bahasa. Hal ini karena penggunaan bahasa yang sama, yaitu bahasa Indonesia. Disampaikan oleh Erna:

"Kalau untuk kegiatan berkomunikasi, rasanya juga tidak ada hambatan. Kalaupun ada, biasanya masalah kecanggungan dalam berbicara. Mungkin di awalawal mengajar kelas yang baru, masing-masing dari kita (saya dan para mahasiswa saya) belum saling mengenal sebelumnya. Terutama mereka, belum mengetahui karakter dosennya. Karena posisi saya sebagai dosen, saya yang lebih banyak berbicara di awal-awal masuk kelas. Saya sendiri tidak tahu, bagaimana persepsi mereka tentang diri saya saat melihat saya pertama kali, apalagi mungkin secara etnis berbeda dengan mereka. Atau, apakah mereka sudah tahu tentang diri saya sebelumnya melalui orang lain (misalnya kakak kelas mereka yang pernah saya ajar). Namun, saya tidak pernah bertanya ke mereka tentang semua hal itu: apakah mereka sudah tahu saya? Apa yang ada dibenak mereka tentang saya saat pertama kali berjumpa? Yang saya tahu, bahwa kita tidak pernah saling mengenal sebelumnya."

Diawal pertemuan (kelas) sangat mungkin terjadi kecanggungan. Hal ini diakui oleh Philip dan Erna. Menurut Philip di awal pertemuan pihak mahasiswa cenderung berhati-hati dalam menilai dosen. Hal ini senada seperti yang disampaikan Erna yang mengatakan bahwa di awal perjumpaan, terjadi kecanggungan dan 
juga persepsi yang ada di benak kita tentang orang yang pertama kali kita jumpai. Karena saya dosen mereka, saya mencoba memahami kondisi tersebut. Karena itulah, saat berbicara pertama kali di hadapan mereka, saya mencoba untuk membuat mereka juga nyaman. Ditambahkan Erna bahwa:

"Kalau dari sisi mahasiswa, yang saya tangkap, mereka cenderung berhati-hati saat mencoba membuka pembicaraan saat saya sedang istirahat pergantian waktu sesi kelas (ada jeda 20 menit istirahat sebelum masuk ke sesi kedua. Kadang saya tetap tinggal di kelas). Dari situ, beberapa di antara mereka mencoba mengajak saya mengobrol. Mungkin ini upaya mereka untuk lebih mengenal dosennya."

Hambatan yang terjadi dalam institusi pendidikan bermuatan komunikasi lintas budaya, bisa saja terjadi baik dari dosen ataupun mahasiswa.

"Hambatan yang saya sebutkan sebelumnya, yaitu kecanggungan saat berbicara dan juga persepsi yang salah, berasal dari mahasiswa. Saya sebagai dosen, tentu sudah memahami kondisi ini (kondisi perbedaan ini). Jadi, saya pun yang harus mencoba memahami mereka. Dari diri saya pun, saya tidak boleh memiliki persepsi yang tidak baik tentang mahasiswa saya. Semua sama. Canggung dalam berbicara pun juga tidak boleh. Bagaimana saya bisa menjelaskan materi kalau saya canggung? Semua hal yang termasuk dalam hambatan berkomunikasi di antara etnis yang berbeda, harus kita atasi. Sebagai dosen, harus bisa bersikap terbuka dan memahami perbedaan. Yang penting, tidak saling mengganggu privasi masing-masing. Untuk bisa lebih memahaminya, kadang saya berupaya untuk bertanya kepada teman mengenai etnis mayoritas tersebut."

Untuk mencairkan suasana di kelas, Erna mengatakan menggunakan bahasa gaul. Agar suasana bisa lebih cair. Baik Philip maupun Erna mengatakan bahwa bahasa menjadi faktor penentu dalam membina komunikasi yang kondusif.

Hubungan pendidikan dengan masyarakat memiliki keterkaitan dan ketergantungan yang sama-sama saling membutuhkan (simbiotic). Masyarakat sangat membutuhkan layanan pendidikan yang baik, dan tentunya hal itu bisa dilakukan melalui lembaga pendidikan guna mempersiapkan diri serta memenuhi kebutuhan dan harapan hidup yang sempurna. Untuk memenuhi hal tersebut lembaga membutuhkan masyarakat agar layanan sesuai dengan keinginannya. Lembaga pendidikan tidak dapat eksis tanpa masyarakat, sebaliknya masyarakat tidak dapat mencapai hidup yang sempurna tanpa lembaga pendidikan.

Ada beberapa cara untuk menghindari kesalahpahaman dalam komunikasi lintas budaya, yang juga terjadi di institusi pendidikan. Diantaranya yaitu: (a) Berpikiran terbuka terhadap dunia luar; (b) Tidak bersikap etnosentris; (c) Berusaha mengakui kebudayaan luar sebagai kekhas-an masyarakat yang memeluknya; (d) Memahami fungsi kita, baik sebagai komunikan ataupun komunikator, serta menghindari feedback yang bersifat negatif.

\section{Kesimpulan}

Berdasarkan pemaparan di atas, sangat jelas diperlukan sikap toleransi dan memahami dalam komunikasi lintas budaya di institusi pendidikan. Baik dosen maupun mahasiswa memiliki peran yang sama pentingnya agar tercapai tujuan pembelajaran yang 
optimal. Dalam proses kegiatan belajar mengajar, dosen dituntut lebih berperan aktif.

\section{Saran}

Mengenai kesiapan pengajar dalam kelas transbudaya dibutuhkan pertama, pentingnya mengembangkan suasana kelas yang nyaman yang mengintegraikan kepercayaan dan nilai dari kelompok budaya. Kedua, menciptakan ruang diskusi dengan topik global. Ketiga, sebaiknya menghindari percakapan membedakan "kita" dan "mereka". Keempat, menghargai nilai dan praktik budaya yang unik. Kelima, perlunya mengembangkan perasaan aman sehingga institusi pendidikan menjadi tempat yang aman dan nyaman untuk menuntut ilmu. Keenam, Empati yaitu (a) berkomunikasilah dengan iklim yang mendukung. Harus dapat menciptakan pesan yang menandakan bahwa anda memahami perasaan dan kebutuhan mereka; (b) pahami komunikasi verbal dan non verbalnya (A.Samovar, 2010: 425).

\section{Daftar Rujukan}

Berger \& Chaffee (Eds). 1987. Handbook of Communication Science. Beverly Hills, California: Sage Publication.

Furuta. (Terj. Hasan Shadili). 1994. Komunikasi Antarbudaya: Sebuah Perbandingan Antara Jepang - Amerika, Jakarta: CV Antarkarya.

Gazalba, S. 1991. Pengantar Kebudayaan Sebagai Ilmu. Yogyakarta: Penerbit Kanisius.

Good, Carter V. 1959. Dictionary of Education. New York: Mc.Graw Hill Book Company.

Gudykunst,William B.(Ed). 1983. Intercultural Communication Theory. Beverly Hills, California: Sage Publications.

Langgulung, H. 1987. Asas-Asas Pendidikan Islam. Jakarta; H. Husna.

Liliweri, Alo. 2001. Gatra-gatra Komunikasi Antarbudaya. Yogyakarta: Gatra.

Mulyana, Deddy dan Rakhmat Jalaluddin (eds.) 2001. Komunikasi Antarbudaya: Panduan Berkomunikasi Dengan Orang-Orang Berbeda Budaya. Bandung: PT Remaja Rosdakarya.

A.Samovar, Larry, E.Porter, Richard and R.McDaniel Edwin (2010) Komunikasi Lintas Budaya: Communication Between Cultures, Salemba Humanika, Jakarta

Sulasman dan Gumilar Setia (2013). Teori-teori Kebudayaan : Dari Teori hingga Aplikasi, Pustaka Setia, Bandung. 
